Jurnal Instruksional, Volume 1, Nomor 2, April $2020 \mid 181$

ISSN: 2686-5645

\title{
PENDIDIKAN ISLAM DALAM PERSPEKTIF KECERDASAN JAMAK (MULTIPLE INTELLIGENCES)
}

\author{
Ansharullah \\ Magister Teknologi Pendidikan, Universitas Muhammadiyah Jakarta \\ email: step_ansharullah@yahoo.com
}

\begin{abstract}
This research stems from a condition which was observed in Indonesian high school. In general the schools do not implement the principles of multiple intelligences comprehensively. Conversely, it is still impressed that the learning is still dominated by one intelligence based education, that is $I Q$ which is cause and effect oriented eductional program. In line with that the learning is filled in the domain of cognition which is commonly oriented at the most basic level of mental development, in which the level of memorization activity is fulfilled the learning process. So that the complex intelligences of the learners' do not develop optimally. This conditions produce that the Indonesian educational products are not optimal. So to improve the quality of education, it is necessary to develop the implementation of learning system which based on the impact of the findings of neuroscience into education, including the development of multiple intelligences (multiple intelligences) in high school level. This research is a qualitative research seeing from philosophical approach and perspective. Along with that, the method used is descriptive, analysis and interpretive. Through philosophical approaches researcher tries to describe the essence of the eight intelligences and their applications in the learning process. With the method of description and interpretation, it is expected to be able to find an interpretation of the concept of multiple intelligences in accordance with socio-religious background of students'. Then by using the analysis method, the application of these findings can be adjusted to the needs and potentials which is available at high school levelled education.
\end{abstract}

Keywords: multiple intelligences, applying multiple intelligence in schools

\begin{abstract}
Abstrak
Penelitian ini bermula dari suatu kondisi yang diamati bahwa pembelajaran di sekolah-sekolah di Indonesia belum menerapkan pendidikan yang berbasis pada pengembangan seluruh kecerdasan jamak. Sebaliknya masih terkesan bahwa pembelajaaran masih didominasi oleh kegiatan yang berbasis pada satu keceredasan saja yaitu kecerdasan IQ dengan orientsi sebab-akibat, sedang materi pembelajaran sudah beragam. Disamping itu ranah pembelajaran yang selalu diisi adalah ranah kognisi pada tingkat perkembangan mental paling dasar yaitu hafalan (memorization), sehingga potensi diri peserta didik tidak berkembang secara maksimal. Kondisi demikian melahirkan produk pendidikan Indonesia tidak optimal. Maka untuk memperbaiki mutu pendidikan tersebut, perlu dilakukan sebuah sistem pembelajaran yang berbasis kepada dampak temuan dari neuroscience ke dalam dunia pendidikan, diantaranya adalah pengembangan kecerdasan jamak (multiple intelligences) disekolah setingkat Sekolah Menengah Atas. Penelitian ini adalah penelitian kualitatif dengan pendekatan filosofis. Seiring dengan itu, metode yang digunakian adalah deskriptif, analisis dan interpretasi, Melalui pendekatan filosofis peneliti berusaha menjabarkan esensi dari delapan kecerdasan tersebut serta aplikasinya dalam proses pembelajaran. Dengan metode deskripsi dan interpretasi, diharapkan dapat ditemukan penafsiran atas konsep kecerdasan jamak sesuai dengan latar belakang peserta didik yang berbasis pada sosio religius. Kemudian dengan menggunakan metode analisis, penerapan temuan tersebut dapat disesuaikan dengan kebutuhan dan potensi-potensi yang tersedia pada pendidikan tingkat SMA.
\end{abstract}

Kata kunci: kecerdasan jamak, gagasan penerapan pendidikan kecerdasan jamak 


\section{PENDAHULUAN}

Tahun 1904, di Perancis, Alfred Binet, bersama Theodore Simon memperkenalkan sebuah tes kecerdasan yang kemudian lebih dikenal dengan nama “Tes IQ" (Intelligence Quetient Tes). Tujuan utama tes tersebut dibuat adalah untuk menentukan pada tingkatan mana dalam pembelajaran seharusnya seorang anak yang IQ nya di bawah standar (retarded) rata-rata. Tes tersebut mendapat tanggapan positif dari pemerintah Amerika Serikat yang selanjutnya digunakan untuk mengukur kecerdasan logika seseorang. Karena satusatunya tes kecerdasan yang ada pada waktu itu adalah tes IQ, maka tes tersebut berpengaruh tidak saja di Amerika, tapi keseluruh dunia termasuk Indonesia.

Hampir delapan puluh tahun tes IQ ini diyakini tes yang hanya dapat mendeteksi keberhasilan seseorang sehingga di dalam pembelajaranpun tes IQ menjadi alat evaluasi utama, untuk mengukur kecerdasan seseorang dan bahkan menjadi model tes untuk evaluasi tahap akhir. Pada hal evaluasi demikian sebetulnya adalah evaluasi satu atau dua kecerdasan saja dari banyak keaneka ragaman kecerdasan yang dimiliki setiap manusia.

Di Indonesia pengaruhnya tidak hanya pada model tes yang berbasis pada kecerdasan IQ tersebut tetapi berkembang seolah-olah sebagai suatu strategi pembelajaran, sehingga proses pembelajaran berlangsung dengan paradigma mengejar target kurikulum lebih penting daripada penguasaan ilmu. Howard Gardner, seorang ahli biopsikologi memberikan kritik terhadap kondisi di atas. Ia mengungkapkan: "Sebagian besar pengujian kita didasarkan pada penghargaan yang tinggi pada keterampilan verbal dan matematika. Bila anda pandai dalam bahasa dan logika, tes IQ, anda pasti bagus, dan anda mungkin berhasil dengan baik masuk peguruan tinggi yang bergengsi, tetapi apakah anda berhasil setelah lulus, mungin akan tergantung pada sejauh mana anda memiliki dan menggunakan kecerdasan yang lain, itulah yang saya beri perhatian yang seimbang (Gardner, 2003: 24).

Pertanyaan yang muncul apakah pembelajaran yang hanya memfokuskan kepada kecerdasan logis matematis dapat mewakili produk pendidikan secara keseluruhan?. Pada hal ada kecerdasan lain selain dari logis matematis yang tidak terlalu terakomodasi. Dari hasil riset Howard Gardner diketahui bahwa setiap manusia yang lahir membawa potensi kecerdasan yang tidak hanya satu melainkan beberapa. Ia menemukan adanya delapan kecerdasan yang dimiliki setiap individu. Kedelapan kecerdasan inilah yang mewakili keunikan setiap individu. Kecerdasan atau kemampuan tersebut berkembang sesuai dengan interaksi antara kemampuan tersebut dengan lingkungan yang berpengaruh terhadapnya.

Undang-Undang RI, No 20 Tahun 2003 Bab V Pasal 12 point (1) b tentang sistem pendidikan nasional. mengamanatkan bahwa setiap peserta didik pada setiap satuan pendidikan berhak mendapatkan pelayanan pendidikan sesuai dengan bakat, minat dan kemampuan. Kemampuan, bakat dan minat pada hakikatnya adalah satu kesatuan yang terbungkus dalam suatu kecerdasan. Wittrock mendefinisikan kecerdasan sebagai fungsi otak keseluruhan yang mencakup kognisi, emosi, intuisi dan indra tubuh. Oleh karena itu pembelajaran yang hanya mengembangkan satu atau dua kecerdasan merupakan tindakan yang tidak sejalan dengan Undang-undang tersebut.

Selanjutnya Undang-Undang RI, No 20 Tahun 2003 BAB II Pasal 3 pun menyatakan bahwa Pendidikan nasional berfungsi mengembangkan kemampuan dan membentuk watak serta peradaban bangsa yang bermartabat dalam rangka mencerdaskan kehidupan bangsa, bertujuan 
untuk berkembangnya potensi peserta didik agar menjadi manusia yang beriman dan bertakwa kepada Tuhan Yang Maha Esa, berakhlak mulia, sehat, berilmu, cakap, kreatif, mandiri, dan menjadi warga negara yang demokratis serta bertanggung jawab.

Para ahli pendidikan mengemukakan bahwa antara peserta didik, pendidik, materi dan metodologi pembelajaran haruslah memiliki kesesuaian. Kesesuaian dalam hal ini berarti bahwa materi dan metodologi harus sesuai dengan potensi peserta didik. Pembelajaran maksimalpun akan terjadi bila perlakuan pendidikan berada dalam satu wadah yang secara keseluruhan memiliki kesesuaian konteks dengan keyakinan yang dimiliki peserta didik.

Penduduk Indonesia yang pada saat ini berjumlah dua ratus tiga puluh satu juta (231.000.000) lebih delapan puluh delapan persen lebih $(88.20 \%)$ atau dua ratus tujuh juta (207.000.105) dari jumlah tersebut beragama Islam (Badan Pusat Statistik dan Pormadi). Persentase tersebut sekaligus mencerminkan populasi pendidik dan peserta didik di Indonesia yang terlibat di dalamnya. Suatu jumlah yang sangat besar dan mendominasi di setiap kelas namun di dalam pembelajaran yang berlangsung selama ini keyakinan agama yang mewarnai kehidupan setiap hari peserta didik dan pendidik terakomodir hanya secara parsial di dalam pembelajaran tersebut.

Di dalam penyelenggaraan pendidikan dan pembelajaran, yang mayoritas peserta didiknya berada dalam konteks keIslaman, namun materi dan metodologi pembelajaran tidaklah sejalan dengan konteks keyakinan peserta didik tersebut, sehingga antara materi dengan peserta didik memiliki jarak yang mengakibatkan tidak menyatunya metodologi dengan potensi diri .

Agama yang alokasi waktunya relative sedikit dan terbatas. hanya dipelajari sebagai suatu pengalaman dan bahkan hanya sebagai suatu kegiatan hafalan, bukan sesuatu yang untuk dijiwai (internalized) yang terintegrasi dengan semua bidang keilmuan. Sehingga hal demikian berdampak pada potensi diri peserta didik yang tidak dapat berkembang karena berada dalam ruang lingkup pengembangan kecerdasan yang parsial dan kebebasan yang terbatas untuk melakukan inovasi. Islam merupakan suatu perbendaharaan yang besar dan kompleks, sebagaimana Firman Tuhan dalam surat Al Maidah ayat 3, yang berbunyi: "Pada hari ini telah $\mathrm{Ku}$ sempurnakan untuk kamu agamamu, dan telah $\mathrm{Ku}$ cukupkan ni'matKu kepadamu serta telah $\mathrm{Ku}$ redhai bagimu Islam itu sebagai agama”.

Jika Islam itu telah disempurnakan Tuhan, maka diyakini agama tersebut mengandung kesempurnaan, yang memungkinkan dapat ditinjau dari aspek yang berbeda baik secara kehidupan dunia maupun akhirat.

Sesuai dengan perintah Tuhan dalam ayat di atas, ummat manusialah yang harus menggali perbendaharaan wahyu tersebut dan bahkan wajib hukumnya. Hal ini diperintahkan Tuhan dalam Surat Al 'alaq ayat $1-3$, sebagai wahyu pertama: "Bacalah! dengan nama Tuhan engkau Yang menciptakan. Dia telah menciptakan manusia dari segumpal darah. Bacalah! dan Tuhan engkau itu maha pemurah" (96: 1$3)$.

Wahyu pertama ini yang diturunkan pada Nabi Muhammad dalam ayat di atas secara harfiah berarti "baca", namun secara makna mendalam adalah "belajar" dan kewajiban "menuntut ilmu". Oleh karena itu dalam ajaran islam wajib hukumnya bagi setiap muslim baik laki maupun perempuan belajar dan menuntut ilmu.

Untuk membentuk suatu kepribadian maka kegiatan pendidikan ditujukan untuk mengembangkan semua potensi belajar baik bersifat fisik maupun bersifat rohani. Dalam hal pendidikan tertuju pada pengembangan rohani tersebut maka, dalam pandangan 
islam pembicaraan itu berkisar kepada potensi qalbu, hati dan jiwa yang di dalam ranah ilmu pengetahuan disebut dengan akal, jiwa dan emosi. Terkait dengan hal di atas, seperti adanya keragaman atau demokrasi dalam metodogi islam, adanya potensi hati, jiwa dan qalbu, maka di dalam disertasi ini penulis berusaha mendalami konsep pendidikan Islam yang utuh atau menyeluruh (holistic), artinya penulis berusaha mendalami semua potensi belajar yang ada di dalam Islam baik qalbu, hati, jiwa atau nafsu. Oleh karena itul penulisan disertasi ini mengambil tema konsep pendidikan Islam yang ditinjau dari perspektif riset yang dilakukan Howard Gardner tentang kecerdasan jamak (multiple intelligences).

Pendidikan Indonesia, khususnya pendidikan Islam di Indonesia secara umum, belum menerapkan konsep kecerdasan jamak (multiple intelligences). Selama ini pengembangan kecerdasan hanya terarah pada pengembangan kecerdasan logis matematis (logical mathematic), linguistik dan sebagian kecerdasan ruang (spatial). Hal demikian disebabkan karena konsep kecerdasan jamak belum terakomodasi secara komprehensif di dalam konsep pendidikan Islam. Kecerdasan jamak yang dimaksud dalam hal ini adalah kecerdasan jamak dalam perspektif Howard Gardner yang berkisar pada konsep, walaupun masih memuat tentang kemungkinan penerapan (implementation) tapi hanya pada sebatas gagasan.

Rumusan masalah penelitian ini adalah: Bagaimana bentuk konsep pendidikan Islam yang ditinjau dari kecerdasan jamak. Artinya apakah di dalam tradisi Islam terdapat konsep pendidikan yang sejalan dengan kecerdasan jamak? Penelitian ini bertujuan untuk menggali bagaimana bentuk konsep pendidikan di dalam tradisi Islam yang ditinjau dari kecerdasan jamak. Diharapkan penelitian ini bermanfaat:
1. Bagi pendidik sebagai pedoman tentang bentuk konsep Islam yang memberdayakan kecerdasan jamak .

2. Bagi para perancang pendidikan untuk mengakomodasi metodologi dan materi pendidikan yang bernuansa Islami bagi peserta didik yang memiliki latar belakang Islam.

3. Bagi para pemerhati.pendidikan untuk menambah wawasan dan menjadi masukan dalam membangun pendidikan berlandaskan kecerdasaan jamak dan agama Islam.

4. Sebagai bahan referensi ke ilmuan bahwa Islam mengakomodasi ilmu pendidikan yang terkait dengan kecerdasan jamak.

\section{KAJIAN LITERATUR Agama Islam}

Islam berasal dari bahasa Arab yang akar katanya adalah aslama, yuslimu, yang berarti berserah diri, patuh dan tunduk. Kata aslama tersebut berasal dari kata salima, yang berarti selamat, sentosa dan damai. Dari pengertian demikian secara harfiah Islam dapat diartikan patuh, tunduk, berserah diri (kepada Allah) untuk mencapai keselamatan di dunia dan akhirat. Di samping Al Quran sebagai alat penyampaian wahyu kepada ummat manusia, Nabi Muhammad juga menggunakan beberapa cara lain, di antaranya dengan berbicara, bertindak, melarang atau bersikap. Semua ucapan, tindak tanduk, sikap Nabi Muhammad tersebut dikumpulkan, dan kemudian dinamakan Sunnah atau Hadis (Al-Hadith).

Perlu dipahami, untuk mengetahui Ayat Al Quran dan hadis secara rinci perlu dilakukan penafsiran (tafsir) terhadap ayatayat tersebut, kegiatan tersebut dinamakan menafsirkan. Kata tafsir berasal dari bahasa Arab (fassara, yufassiru) yang berarti penjelasan, pemahaman dan perincian dan lebih lanjut diartikan membuka atau menyingkap (Wehr, 1974, dalam Abuddin Nata 1999). 
Agama islam meyakini bahwa manusia terdiri dari dua unsur yaitu jasmani dan rohani, Rohani dilengkapi dengan empat organ yaitu nafsu, akal, qalbu dan roh. Sudirman Tebba mengemukakan tentang organ rohani yang disebutkan di atas. "Ketika jiwa mengorientasikan pandangannya ketempat asal, ia disebut ruh. Ketika melakukan aktivitas berfikir rasional atau penalaran diskursif, ia disebut akal. Ketika mendapatkan pencerahan dari Allah ia disebut hati (qalbu). Ketika ia berhadapan dengan tubuh ia disebut jiwa" (Tebba, 2008: 10). Menurut keterangan di atas bahwa manusia terdiri dari dua unsur, yaitu jasmani dan rohani, Rohani dilengkapi dengan empat organ yaitu roh, nafsu (jiwa), qalbu dan akal.

Roh (ar-ruh) adalah hakikat dari manusia yang dengannya manusia dapat hidup dan mengetahui segala sesuatu. Qalbu (hati) adalah ketika jiwa mendapatkan pencerahan dari Allah. Hati (qalb) memiliki empat stasiun: dada, hati, hati-lebih-dalam dan lubuk hati terdalam. Akal adalah daya berfikir yang ada dalam diri manusia dan merupakan salah satu daya dari jiwa serta mengandung arti berfikir, memahami (Tebba, 2008: 10). Oleh karena itu yang menjadi prinsip utama pendidikan dalam pandangan islam adalah pelibatan secara holistik seluruh potensi belajar yang ada dalam diri seorang individu, apakah itu rasio, emosi, spiritual maupun seluruh unsur lingkungan yang berpengaruh dalam pendewasaan. Kompleksitas agama Islam, memberikan kesempatan kepada manusia untuk membangun potensi dirinya sebagai rahmat Tuhan padanya.

Hal ini terkait dengan pendidikan Islam yang membebaskan umat manusia dari keterbelengguan karena pandangan bahwa kecerdasan itu hanya tunggal belaka. Untuk membebaskan umat manusia dari keterbelengguan tersebut perlu pengakomodasian potensi diri yang beragam dalam pendidikan yang dimulai dengan bakat, minat dan kemampuan.

Keempat aspek di atas mencerminkan bahwa ajaran Islam memiliki beberapa cara atau pendekatan terhadap Tuhan yang sangat berpengaruh kepada prilaku, kepribadian dan cara berfikir setiap individu. Hal ini berarti bahwa Islam melibatkan potensi manusia secara utuh yang berusaha mensinergikan rasio, emosi dan jiwa. Sekali gus hal ini juga menunjukkan bahwa agama Islam merupakan suatu kesatuan yang utuh (holistik) dan berprinsip pluralistik yang bisa menerima perbedaan, maka dari itu Islam merupakan agama yang rahmatan lilalamin.

\section{Makna Pendidikan}

Secara umum para ahli pendidikan memaknai pendidikan sebagai usaha sadar pendewasaan jasmani dan rohani untuk membentuk suatu kepribadian yang mengandung nilai-nilai. Di Indonesia hal di atas diperkuat dengan Undang-undang RI No.20 Th.2003 tentang sistem pendidikan Indonesia Bab I, Pasal 1, point 2, yang berbunyi Pendidikan nasional didefinisikan sebagai: "usaha sadar yang disengaja dan terencana untuk mewujudkan suasana belajar dan pembelajaran agar peserta didik secara aktif mengembangkan potensi dirinya untuk memiliki kekuatan spiritual keagamaan, pengendalian diri, kepribadian, kecerdasan, akhlak mulia, serta keterampilan yang diperlukan dirinya, masyarakat bangsa dan negara" (Undang-undang RI Nomor 20 tahun 2003).

Keterangan di atas menunjukkan bahwa pendidikan merupakan usaha sadar yang terencana untuk mengembangkan potensi diri peserta didik agar memiliki kekuatan spiritual keagamaan pengendalian diri, kepribadian, kecerdasan, akhlak mulia, serta keterampilan. Perkembangan lebih jauh tentang pendidikan yang ditinjau dari sudut pandang Teknologi Pendidikan, Knezevich dan Eye sebagaimana dikutip oleh Gentry, (1991:5) menyatakan: "teknologi pendidikan 
adalah suatu usaha memanipulasi lingkungan hidup manusia dengan maupun tanpa mesin baik yang tersedia maupun yang di manfaatkan agar terjadi perubahan prilaku atau hasil belajar" (Sells: 10).

Dari keterangan di atas dapat diambil pengertian bahwa pendidikan diartikan lebih khusus sebagai usaha memanipulasi lingkungan untuk terjadinya perubahan prilaku atau hasil belajar baik dengan pemanfaatan mesin atau teknologi ataupun tidak dengan mesin. Dalam pandangan teknologi pendidikan dan kecerdasan jamak bahwa suatu keberhasilan ditentukan oleh bagaimana memanfaatkan lingkungan yang bersinergi dengan potensi diri. Untuk mendapatkan hasil maksimal dari suatu pembelajaran semua unsur potensial pendidikan harus dilibatkan baik pendidik, peserta didik, materi, motivasi, situasi dan kondisi serta latar belakang budaya dan agama dari peserta didik maupun pendidik.

\section{Dampak Neuroscience}

Untuk penelaahan lebih lanjut tentang pendidikan, terlebih dahulu perlu diperjelas tentang neuroscience. Neuroscience merupakan suatu cabang ilmu tentang fungsi dan cara kerja otak manusia. Fungsi kerja otak manusia bekerja sangatlah unik, cara kerja kedua belahan otak yaitu belahan otak kiri dan belahan otak kanan melakukan fungsi yang berbeda. Begitu juga halnya dengan bagian otak yang terkait dengan pengendalian emosi seperti amigdala yang menghubungkan antara emosi dan rasio. Dari keseluruhan fungsi otak, dapat dikatakan bahwa otak merupakan pusat pengendalian seluruh aktivitas tubuh manusia. Perlu diungkapkankan bahwa seluruh kepribadian manusia terbentuk dari kombinasi faktor genetik dan faktor lingkungan.

Langkah pertama perlu dipaparkan tentang faktor genetik, karena faktor ini terkait langsung dengan potensi diri yang berada dalam diri seorang individu. Dobz
Hansky, (1964), dalam Clark menegaskan bahwa: "The genotype and the environment are equally important, because they are indispensable. There is no organism without genes and any genotype can act only in same environment" (Clark, 1986: 8). Keterangan ini menyatakan bahwa, gen dan lingkungan sama pentingnya, keduanya saling memerlukan. Tidak ada sebuah organisme yang tidak membutuhkan gen, dan sebaliknya sebuah gen hanya dapat berkembang jika berada dalam lingkungan yang sesuai. Hal tersebut diperkuat oleh penelitian seorang Neurologist T. Tyler, dalam Clark, menurutnya, "the fabric of the brain is set down as a result of the intereaction of genetics blueprints and environtmental influences" (Clark, 1986: 8). Struktur (fabric) otak merupakan produk dari interaksi cetakbiru (rancangan) genetis dengan pengaruh lingkungan.

Lebih lanjut, Rosenzweig (1966) dalam Clark menjelaskan, tentang pengaruh penataan lingkungan terhadap struktur sel, "...as we change the environment, we affect the genetic or biological structure of the organism ...we must be aware that the decisions for environmental intervention do, in fact, change the neurological and biological structure of the living organism. By the environment we provide, we change not just behaviour of children, we change them at cellular level" (Clark, 1986: 8).

Keterangan di atas menunjukkan bahwa, begitu sebuah lingkungan berubah maka struktur genetik dari sebuah organism langsung terkena dampak. Suatu perubahan haruslah dilakukan berhati-hati karena hal itu dapat merubah struktur bilogis dan neurologis dari sebuah organisme yang hidup. Hal di atas mengandung pengertian bahwa lingkungan yang dihadirkan pada seorang anak tidak hanya dapat merubah tingkah laku tetapi juga dapat merubah alat belajar yang begitu kecil dan utuh sampai kepada tataran sel yang bersifat mandiri. Alat belajar secara keseluruhan adalah 
semua organism yang membentuk potensi belajar anak; otak, emosi, dan kecerdasan. Otak merupakan pusat berfikir, prilaku serta emosi manusia yang mencerminkan seluruh diri seorang individu. Roger Wolcott Sperry dalam Conny Semiawan, pada tahun 1940 menemukan fungsi khusus belahan otak dan masih bersifat stereotip laki-laki dan perempuan. Laki-laki berfikir logis, rasional, agresif, strategis, kompetitif dan pembuat keputusan, sedangkan perempuan lebih berfikir intuitif, emosional, spontan, submisif dan kooperatif, lebih banyak pula perempuan sebagai pengikut (Semiawan, 1997: 55).

Pernyataan Sperry di atas menunjukan bahwa belahan otak kiri lebih cenderung kearah berfikir teratur, linear, matematis dan faktual, dan lebih memiliki daya untuk bersaing. Berfikir cara di atas lebih identik dengan cara berfikir seorang laki-laki. sedangkan belahan otak kanan lebih cenderung kepada cara berfikir imaginatif, emosional, pengikut, spontan, intuitif dan kreatif. Hal ini lebih menunjukkan kepada cara berfikir seorang perempuan. Kemudian Wittrock pada tahun (1980) menjelaskan tentang fungsi kerja kedua belahan otak. "The left brain is most responsible for linear, sequential, analytic, rational thinking, reading, language, the computational aspects of mathematics, the inquirer, and the critic are located in this hemisphere. Thought of a methaporic, spatial, holistic nature is the province of the right hemisphere" (Clark, 1986: 24).

Dalam perkembangan lebih lanjut Wittrock memperjelas bahwa fungsi dan cara kerja belahan otak kiri adalah linear, teratur, analisi, berfikir rasional membaca, berbahasa, matematis, mengeritik dan kegiatan mencari jawaban yang tajam dan mendalam. Sedangkan belahan otak kanan lebih cenderung kepada cara berpikir simbolik, imaginatif, ruang (spatial) keseluruhan (holistic nature).
Jika materi hanya diarahkan untuk satu fungsi otak saja, misalnya untuk belahan otak kiri, maka pendidikan tidak memiliki produk dengan nilai-nilai kreatifitas, dan jika untuk otak kanan saja maka produk pendidikan akan lebih terfokus pada imaginasi saja tanpa sistematika. Kesinergian kedua belahan otak memungkinkan fungsi kerja otak meningkat menuju kepada kondisi kreatif yang pada gilirannya membuahkan kreativitas yang tetap tanpa harus mengeluarkan energi besar. Siler Lebih lanjut menegaskan tentang kemampuan manusia: "We are all born with the ability to create, explore, learn, discover and invent that is, to metaphorm. According to him the word "metaphorming" is derived from the Greekwords, "meta" is transcending, while "phora" is transference. It refers to the act of changing something from one state of matter and meaning to another" (Siler, 1999: 8).

Keterangan di atas diterjemahkan sebagai berikut, semua manusia lahir dibekali dengan suatu kemampuan mencipta, menggali, belajar, menemukan, dan mencipta temuan baru. Inilah yang disebut dengan metaphorming. Kata tersebut berasal dari Greek (Yunani) yang terdiri dari kata "meta" berarti besar (transcending), sementara "phora" berarti transcending, while "phora" adalah proses perpindahan (transference), keduanya berarti merobah sesuatu menjadi yang lain.

Otak yang bekerja secara kreatif, akan merobah fungsi otak tersebut satu tingkat lebih baik di atas rata-rata. Artinya bakat pada mulanya merupakan sebuah potensi saja, namun kemudian dapat menjadi kecerdasan, pada tingkat yang lebih tinggi jika mendapatkan rangsangan dan latihan yang baik selama mengalami masa perkembangannya.

Pengembangan potensi diri sebaiknya berjalan seiring dengan lingkungan, hal ini dimaksudkan untuk membentuk kemampuan intelektual seorang anak manusia yang 
berimbang. Kecerdasan menurut Cattell (1971), digambarkan sebagai berikut: "intelligence is a composite or combination of human traits, which includes a capacity for insight into complex relationships, all of the processes involved in abstract thinking, "adabtability in problem solving, and capacity to acquire new capacity" (Clark, 1986: 8).

Kecerdasan menurut Cattell merupakan kombinasi dari sifat-sifat manusia yang mencakup kemampuan untuk memahami hubungan kompleks, semua proses yang dilakukan terlibat dalam berfikir abstrak, "kemampuan menyesuaikan diri pemecahan masalah dan kemampuan untuk memperoleh kemampuan baru". Pada tahun 1980 Wittrock dalam Clark memperjelas pengertian tentang kecerdasan, menurutnya, intelligence can no longer be confined to cognitive function, but clearly must include all of the function of the brain and their efficient and integrated use. Intelligence is defined in this text as total and integrated all brain functioning, which includes cognition,emosion, intuition, and physical sensing (Clark, 1986: 8).

Kecerdasan tidak hanya terbatas pada fungsi kognisi saja, namun harus mencakup fungsi otak dan penggunaan yang tepat serta terintegrasi. Oleh karena itu kecerdasan harus didefinisikan sebagai fungsi otak keseluruhan yang mencakup kognisi, emosi, intuisi dan indra tubuh. Baru pada tahun 1983, seorang psikolog dari Universitas Harvard, Howard Gardner, mempersoalkan pengertian kecerdasan yang selama itu mengisi pikiran masyarakat. Ia mendefinisikan kecerdasan sebagai berikut: "I now conceptualize an intelligence as a biopsychological potential to process information that can activated in a cultural setting to solve problems or create products that are of value in a culture" (Gardner, 1999: 34).

Menurut Gardner, kecerdasan adalah suatu potensi biopsikologi untuk memproses informasi yang dapat menempatkan diri (activated) di dalam suatu budaya tertentu untuk pemecahan masalah atau mencari jalan keluar dari suatu permasalahan dan menciptakan pemikiran (produk) baru yang bernilai atau berguna di dalam budaya tersebut. Namun definisi Gardner lebih melibatkan dua aspek yaitu psikologi atau jiwa dan pisik, sedangkan definisi Cattell lebih cenderung pada faktor kejiwaan saja dengan menggunakan terminologi kepribadian manusia (human traits). Dari hasil risetnya ia menegaskan bahwa, pada waktu itu paling tidak ada tujuh kecerdasan yang terdapat dalam diri setiap individu bukan hanya satu (IQ) saja, kemudian tidak lama berselang, ia menemukan kecerdasan yang kedelapan.

Berikut ini Gardner memberikan deskripsi tentang kemampuan manusia menjadi delapan kemampuan dasar. Kesatu, Kecerdasan Linguistik (Linguistic Intelligence), Kedua, Kecerdasan LogisMatematis (Logical-Mathematical Intelligence), Ketiga, Kecerdasan VisualSpasial (Spatial Intelligence). Keempat, Kecerdasan Musikal (Musical Intelligence), Kelima, Kecerdasan Kinestetis (BodilyKinesthetic Intelligence). Keenam, Kecerdasan Interpersonal (Interpersonal Intelligence), Ketujuh, Kecerdasan Intrapersonal (Intrapersonal Intelligence). Kedelapan Kecerdasan naturalis. (Gardner, 1999: 73-276, 48). Kedelapan kecerdasan tersebut digambarkannya sebagai berikut.

Pertama, kecerdasan berbahasa: "Linguistic Intelligence, involves sensitivity to spoken and written language, the ability to learn languages, and the capacity to use language to accomplish certain goals" (Gardner, 1999: 48). Gardner menyatakan dalam kecerdasan berbahasa melibatkan kepekaan (sensitivity) terhadap penguasaan bahasa lisan dan tulisan dan kesanggupan untuk menggunakan bahasa tersebut dalam meraih tujuan tertentu. 
Kedua, kecerdasan logis matematis: "Logical-Mathematical Intelligence involves the capacity to analyze problem logically, carry out mathematical operation, and investigates issues scientifically" (Gardner, 1999: 42). Di dalam keterangan ini Gardner menyatakan bahwa Kecerdasan logis matematis melibatkan kesanggupan (capacity) untuk menganalisis problem secara logis, mengatsi problem matematika serta sanggup menginvestigasi suatu permasalahan sesuai kaidah keilmiahan.

Ketiga, kecerdasan ruang: "Spatial Intelligence features the potential to recognize and manipulate the patterns of wide space as well as as the pattern of more confined area" (Gardner, 1999: 42). Gardner menyatakan dalam keterangan di atas bahwa kecerdasan ruang (spatial) memiliki potensi untuk mengenal dan memanipulasi 'pola ruang yang luas seperti pekerjaan yang terkait dengan nakoda kapal atau pilot dan pola ruang yang relatif kecil seperti pembuatan ukiran, lukisan dan miniatur, pembedahan oleh dokter bedah dan permainan catur.

Keempat, kecerdasan musik: "Musical Intelligence entails skills in the performance, composition and appreciation of musical patterns" (Gardner, 1999: 42). Gardner menyatakan dalam keterangan di atas bahwa kecerdasan musik terkait dengan kepiawaian dalam menampilkan, mengarang dan menyusun serta mengapresiasi pola musik. Kelima, kecerdasan raga (fisik): Bodily Kinesthetic Intelligence entails those parts of the body to solve problems or fashion products. potential of using one's whole " (Gardner, 1999: 42). Di dalam keterangan di atas Gardner menyatakan bahwa kecerdasan raga (Bodily Kinesthetic) melibatkan kesanggupan anggota badan untuk mengatasi masalah atau tampil dihadapan publik dan memiliki potensi untuk menggunakan pisik secara keseluruhan.
Keenam, kecerdasan hubungan sosial: “Interpersonal Intelligence denotes person's capacity to understand the intenstions, motivasions, and desires of other people and, consequently, to work effectively with others" (Gardner, 1999: 43). Gardner menyatakan dalam keterangan di atas bahwa kecerdasan hubungan sosial (Interpersonal Intelligence) menunjuk kepada suatu kapasitas untuk memahami keinginan (intenstions) dan motivasi seseorang. Hal ini juga terkait dengan kehendak atau keinginan orang lain serta bisa bekerja sama dengan pihak lain tersebut. Ketujuh, kecerdasan diri pribadi: "Intrapersonal intelligence involves the capacity to understand oneself, to have an effective working model of oneself including one's own desires, fears, and capacities and to use such information effectively in regulating one's own life (Gardner, 1999: 43). Gardner menyatakan dalam keterangan di atas bahwa kecerdasan diri pribadi (Intrapersonal intelligence) merupakan kemampuan untuk memahami diri sendiri yang terkait dengan kelebihan dan kekurangan, model dan cara kerja. Hal demikian juga termasuk keinginan, ketakutan serta kemampuan untuk memanfaatkan informasi secara efektif dalam mengatur kehidupan sendiri.

Kedelapan, kecerdasan naturalis: "Natural Intelligence, denotes the capacity to demonstrate expertise in the recognition and classification of the numerous species -the flora and the fauna -of his or her environment... ... A naturalist is a biologist who recognize and categorized specimens ... and extensive knowledge of the living world" (Gardner, 1999: 48). Di dalam keterangan ini Gardner menyatakan bahwa kecerdasan naturalis (natural) melibatkan kapasitas untuk mengklasifikasikan dan memahami kehidupan dari makhluk hidup flora dan fauna. Dalam skala luas kecerdasan ini terkait dengan alam mikro dan makro kosmos. 
Menurut Gardner, setiap individu memiliki ke delapan jenis kecerdasan tersebut di atas, hanya saja tingkat perkembangan dari masing-masing kecerdasan berbeda pada satu individu dengan individu lainnya. Lebih lanjut Gardner menegaskan bahwa "Although we all receive these intelligences as part of our birthright no two people have exactly the same intelligences in the same combinations. After all, intelligences arise from the combinations of a persons's genetic heritage and life conditions in a given culture and era" (Gardner, 1999: 41).

Keterangan di atas menyatakan bahwa Setiap individu memiliki ke delapan jenis kecerdasan sebagai bagian dari hak azazi alami manusia yang terlahir. Tidak akan ada dua orang memiliki kombinasi kecerdasan yang sama, karena kecerdasan merupakan kombinasi dari dua faktor yaitu turunan (genetic) dengan faktor lingkungan atau kondisi dan situasi dalam suatu budaya dan dalam suatu kurun waktu atau era. Oleh karena itu setiap individu akan berbeda satu dengan yang lainnya sesuai dengan kadar kombinasi dan perkembangan dari masingmasing kecerdasan

Ada tiga hal yang dapat disimpulkan dari temuan riset Howard Gardner, Pertama, kecerdasan bukan hanya merupakan kemampuan jiwa atau berfikir tapi juga merupakan kemampuan fisik. Kedua, kecerdasan tidak hanya tunggal melain jamak, didalam diri seorang indvidu terdapat delapan kecerdasan. Ketiga, kecerdasan seseorang dibangun dari gabungan antara warisan genetis (genetic heritage) dan lingkungan atau sautu kondisi kehidupan dalam suatu budaya dan pada suatu kurun waktu atau era.

\section{METODE PENELITIAN Pendekatan Penelitian}

Penelitian ini bertujuan untuk menemukan konsep pendidikan Islam yang di tinjau dari sudut pandang kecerdasan jamak. Kerangka berfikir yang digunakan adalah kecerdasan jamak dari sudut pandang Howard Gardner. Kecerdasan jamak yang dimaksud adalah kedelapan kecerdasan yang ditemukan oleh Howard Gardner dalam penelitiannya pada tahun 1983. Sedangkan kecerdasan lain hanya disinggung sepanjang ada kaitannya dengan kecerdasan jamak (multiple Intelligence). Kegiatan yang dilakukan dalam penelitian ini adalah menggali dan menginterpretasi ayat-ayat, hadis dan pemikiran para tokoh. Data yang dihasilkan dari penelitian ini adalah berupa uraian dan paparan pendapat, oleh karena itu tergolong ke dalam penelitian kualitatif.

Penelitian dilaksanakan dari bulan Juni 2007 sampai dengan Mai 2010 di Jakarta. Penelitian ini adalah penelitian Filsafat (philosophy Inquiry). Menurut Archie, "Since the study of philosophy involves working with concepts rather than facts, the activity of philosophy seeks understanding rather than knowledge. In other words, emphasis in this course of study is placed on the reasoning process. Memorizing the subject matter of philosophy is less likely to give insight into the discipline than is engaging actively in process doing philosophy" (Archie, 2004: 22). Keterangan di atas menunjukkan bahwa studi tentang filosofi melibatkan konsep yang sangat bersifat mendasar bukan terkait dengan penghadiran fakta yang bersifat kasat mata. Kegiatan filsafat tersebut merupakan kegiatan untuk membangun sebuah konsep pemahaman (understanding) yang bersifat abstrak yang penekanannya terletak pada proses rasional (reasoning process). Kegiatan yang dilakukan merupakan interpretasi makna dari suatu teks, wacana atau sebuah pengertian. Secara khusus penelitian ini disebut dengan penelitian filsafat (Philosophical Inquiry).

Dalam usaha membangun pengertian atau makna peneliti berusaha memahami sumber secara mendalam, menyeluruh dan 
berusaha memahami hakikat atau makna dari ayat-ayat, hadis dan informasi yang berkaitan dengan hal itu, seperti pemikiran dan praktek para tokoh pendidikan Islam. Peneliti berupaya menelaah dan memahami pengertian yang dalam dari ayat-ayat yang terkandung dalam kitab suci dan Hadis serta mengikuti perkembangan pemikiran para tokoh Islam melalui karyanya. Penelitian ini menampilkan implikasi dalam bentuk gagasan penerapan di dalam pendidikan.

Metode penelitian ini adalah metode komparatif yang membandingkan dua aliran yaitu Islam dan dampak temuan kecerdasan jamak. Penelitian ini dimulai dengan mengumpulkan data dan sumber kepustakaan dengan membandingkan pandangan para ahli tafsir Islam dengan pendapat Howard Gardner tentang dampak kecerdasan jamak. Kemudian ayat dikumpulkan sesuai tema (mawdhu'iy). Di dalam penelitian ini yang dibandingkan adalah "persamaan dalam satu perspektif", dengan tujuan mencari pemikiran yang lebih mantap dan definitif, sehinga penelitian ini memberikan pengertian baru, dan memperjelas garis masing-masing pandangan.

Persamaan yang dimaksud adalah potensi apa yang terdapat di dalam konsep pendidikan Islam jika dilihat dari sudut pandang kecerdasan jamak versi Howard Gardner. Potensi diri meliputi bakat, kecerdasan jamak (multiple Intelligence), Sedangkan potensi lingkungan mencakup unsur manusia seperti guru, teman masyarakat dan unsur materi seperti media elektronik maupun cetak serta metodologi pembelajaran.

\section{Objek, Sumber dan Langkah Penelitian}

Obyek penelitian ini adalah bakat dan kecerdasan manusia, yang dikhususkan kepada kecerdasan jamak (multiple intelligence), sedangkan kecerdasan emosi dan kecerdasan spiritual, disinggung seperlunya jika terkait dengan multiple intelligences. Sumber penelitian ini adalah Al Quran dan Hadis serta pemikiran para tokoh pendidikan Islam.

Di dalam penelitian ini yang bertindak sebagai key instrument adalah peneliti sendiri, yang secara aktif terjun ke lapangan dan ke perpustakaan untuk mengumpulkan informasi dan data dari berbagai sumber. Langkah yang dilakukan dalam penelitian ini adalah:

1. Membaca Al Qur'an dan hadis untuk menemukan ayat-ayat yang diduga mengandung pikiran pendidikan dan potensi kecerdasan. Sebagai langkah awal peneliti menggunakan terjemahan dan tafsir Al Quran.

2. Memberi tanda setiap ayat-ayat Al qur'an dan hadis yang diduga mengandung pendidikan dan potensi kecerdasan.

3. Kemudian mencatat nomor ayat serta nomor surat yang diduga terkait dengan ayat pendidikan dan potensi kecerdasan.

4. Menelaah kandungan ma'na ayat-ayat yang telah ditandai tersebut baik secara ma'na tersurat dan maupun ma'na tersirat.

5. Mengumpulkan dan menelaah pemikiran para tokoh pendidikan Islam.

\section{Teknik Analisa Data}

1. Setelah usaha penggalian terhadap ayat ayat yang terkait dengan pendidikan dan potensi kecerdasan, maka data tersebut dipaparkan dengan pendekatan kategorisasi.

2. Dalam kategorisasi, dilakukan dengan; pemisahan makna dari ayat-ayat yang bernuansa pendidikan secara umum, pemisahan makna terhadap ayat-ayat yang bernuansa kecerdasan manusia, mengklasifikasikan makna ayat-ayat yang bernuansa kecerdasan manusia. Lebih lanjut ayat-ayat tersebut dianalisa dengan mengacu kepada konsep ilmu pendidikan, 
Jurnal Instruksional, Volume 1, Nomor 2, April $2020 \mid 192$

ISSN: 2686-5645

potensi kecerdasan manusia. Kemudian

analisa terakhir kearah aplikasi pembelajaran.

\section{HASIL DAN PEMBAHASAN Pendidikan Islam Berbasis Kecerdasan Jamak}

Pendidikan Islam merupakan bimbingan yang secara sadar diberikan oleh seorang pendidik terhadap peserta didik dalam usaha mengembangkan jasmani dan mendewasakan rohani yang seimbang dan menyeluruh agar terbentuknya kepribadian utama sesuai dengan keyakinan agama Islam. Pertumbuhan jasmani yang dimaksud dalam Islam adalah pengembangan aspek fisik. Sedangkan rohani merupakan kemampuan dan kekuatan pendorong yang tidak terlihat dengan indra fisik.

Ada dua pendapat tentang lokasi rohani. Pendapat pertama menyatakan dimensi rohani adalah ranah otak karena secara lahiriah otak merupakan sentral atau pengendali aktivitas dan kehidupan manusia. Yang kedua berpendapat bahwa dimensi rohani berada pada ranah masing-masing dan bersifat mandiri satu sama lain, potensi tersebut disebut jiwa ( $n a f s$ ) dan qalbu. Oleh karena itu penulis mencoba menghadirkan beberapa pendapat tentang pendidikan yang menyentuh wilayah rohani.

Jika dihubungkan antara dunia Islam dengan dunia ilmu pengetahuan tentang perihal kecerdasan maka bakat tidak bisa tidak merupakan potensi belajar di dalam dunia pendidikan yang sangat utama. Oleh karena diskusi ini dimulai dengan bahasan tentang bakat dalam pandangan Islam. Sebagaimana yang dirumuskan oleh para ahli, bakat yang sudah ada di dalam diri manusia dimaknai sebagai yang inherent (telah ada dan menyatu di dalam diri seseorang) dibawa sejak lahir dan terkait dengan struktur otak. Sekaligus bakat membedakan setiap individu dan malah merupakan keunikan yang satu dari lainnya.
Keterangan di atas menjelaskan bahwa bakat merupakan potensi tersembunyi dibawa sejak lahir yang telah melekat dengan keperibadian seseorang. Namun harus diketahui bahwa bakat merupakan potensi yang siap diaktualisasikan dan berkembang lebih baik jika terjadi sinergi dengan lingkungan yang mendukung disekitarnya. Di dalam Al Qur'an surat Ar Rum ayat 30: Allah berfirman: "Maka hadapkanlah wajahmu dengan Lurus kepada agama Allah; (tetaplah atas) fitrah Allah yang telah menciptakan manusia menurut fitrah itu" (QS. Ar Rum (30): 30). Secara tekstual pengertian dari terjemahan tersebut adalah "menghadapkan wajahmu (umat manusia)" kepada agama yang diridhai Allah, tetapi dalam makna kontekstual "menghadapkan wajahmu" kepada agama Allah merupakan kegiatan aktualisasi diri yang bermakna konotasi dan bersifat dinamis. Mempelajari agama Allah sesuai dengan potensi diri manusia. Kata "menghadapkan" tidaklah hanya berarti "memperlihatkan" melainkan kata tersebut memiliki arti yang lebih luas seperti berjuang, bekerja, belajar dan curahkan.

Arti tersebut di atas dijabarkan lebih dalam tafsir berikut ini. Bachtiar Surin dalam tafsir Adz-Zhikra menjelaskan: "Arahkanlah pandangan hidupmu lurus-lurus kepada agama Allah, sesuai dengan fitrah (kodrat jiwa). Allah telah menciptakan manusia serasi dengan fitrah kejiwaannya. Tidak ada suatu perubahan dalam ciptaan Allah tadi. Itulah agama yang lurus tetapi kebanyakan manusia tidak mengetahui'" (QS. 30: 30), (Bachtiar, 1991: 1716).

Ayat Al Qur'an dan hadits di atas menyatakan bahwa anak manusia semenjak lahir telah membawa fitrah atau kodrat kejiwaan yang diwarisi dari orang tuanya. Kodrat tersebut merupakan potensi atau kemampuan yang merupakan kekuatan dirinya untuk mencari kebenaran atau mengabdi kepada Tuhan. 
Hadits riwayat Bukhari Muslim berikut ini berbunyi: "Ayah dan Ibunyalah yang menjadikan anak tersebut Yahudi, Nasrani ataupun Majusi” (Hadits riwayat Bukhari Muslim). Hadis ini menunjukkan bahwa fitrah merupakan suatu potensi yang bisa diarahkan, dibentuk dan dikembangkan oleh lingkungan. Dalam hal ini "ayah dan ibu" sebagai faktor lingkungan memiliki potensi mengarahkan. Jika fitrah merupakan suatu potensi yang dibawa semenjak lahir, sedangkan bakat juga merupakan suatu potensi yang dibawa dari lahir maka antara fitrah dan bakat dalam konteks di atas memiliki suatu pengertian yang sama. Pada kondisi yang sama, bakat dan fitrah inilah yang dimaksud Howard Gardner sama dengan kecerdasan. Howard Gardner memberi definisi kecerdasan yang jamak itu, sebagai suatu kemampuan mengatasi masalah dan melahirkan ide atau pemikiran baru yang tepat guna di dalam suatu struktur budaya.

Dalam hal potensi yang dibawa semenjak lahir ada kesamaan antara bakat dengan kecerdasan jamak. Namun dalam hal pengertian yang bersumber dari definisi, maka kecerdasan jamak lebih kompleks dan explicit. Bedanya adalah pengertian kecerdasan jauh lebih luas jika dibandingkan dengan bakat yang hanya sekedar suatu kemampuan tersembunyi yang melekat di dalam diri seseorang semenjak lahir. Di dalam Islam ditemukan tentang kecerdasan melalui Firman Tuhan dalam Al Quran surat An Nahl ayat 78, yang berbunyi: "Dan Allah mengeluarkan kamu dari perut ibumu dalam keadaan tidak mengetahui sesuatu pun dan Dia memberi kamu pendengaran, penglihatan, dan hati agar kamu bersyukur" (QS.16:78). "and God has brought you forth from your mother's womb knowing nothing, but He has endowed you with hearing and sight, and minds so that you might have cause to be grateful" (Asad, 2003).

Ayat di atas menunjukkan bahwa Tuhan memberikan manusia kecerdasan pendengaran, penglihatan, dan hati atau akal. Menurut Muhammad Asad, "pendengaran" dan penglihatan merupakan alat kecerdasan untuk pemerosesan informasi sebagai fungsi kerja otak. Kemudian hati berarti otak atau akal sebagai kecerdasan itu sendiri. Kedelapan kecerdasan tersebut digambarkannya sebagai berikut:

Pertama, kecerdasan berbahasa; kecerdasan linguistik terkait dengan kemampuan menggunakan kata secara efektif, baik secara lisan maupun tertulis. Secara praktis dapat dikatakan bahwa kecerdasan linguistik merupakan kemampuan untuk menyampaikan pesan pikiran melalui komunikasi lisan maupun tulisan. Gardner menyatakan bahwa kecerdasan berbahasa melibatkan kepekaan (sensitivity) terhadap penguasaan bahasa lisan dan tulisan dan kesanggupan untuk menggunakan bahasa tersebut dalam meraih tujuan tertentu. (Linguistic Intelligence, involves sensitivity to spoken and written language, the ability to learn languages, and the capacity to use language to accomplish certain goals).

Dalam penyampaian tersebut perlu dilakukan pertimbangan yang terkait dengan ketepatan penggunaan bahasa (appropriateness). Hal ini dimaksudkan penggunaan bahasa yang jelas secara bunyi dan memperhatikan kaidah tata bahasa serta mempertimbangkan dimana dan kapan seseorang berada ketika mengungkapkan ujaran bahasa tersebut. Di dalam konsep sosiolinguistik ketepatan berbicara dinyatakan dengan formula berikut: "siapa berbicara dengan siapa, tentang apa, dimana, dan kapan" (who speak to whom, about what, where, and when).

Di dalam agama Islam kecerdasan linguistik ini mendapat tempat yang sangat penting, sebagaimana perintah Tuhan dalam Firman Nya Surat Al-Baqarah ayat 83: "Ucapkanlah kata-kata yang baik kepada manusia” (QS. Al Baqarah (2): 83). Bahwa setiap manusia diperintahkan oleh Tuhan 
untuk menggunakan kata-kata yang baik dalam berhubungan dan berbicara dengan sesama manusia. Kata-kata yang baik itu merupakan produk pilihan sebelum diucapkan oleh seseorang terhadap orang lain dalam bentuk ujaran bahasa yang dihasilkan melalui perangkat artikulasi di dalam diri manusia.

Lebih lanjut, dalam Hadits yang diriwayatkan oleh Muslim. Nabi Muhammad bersabda: "Barang siapa yang iman kepada Allah dan hari akhir, maka hendaklah ia berbicara yang baik-baik atau hendaklah diam saja." Dalam Hadits tersebut dijelaskan bahwa seseorang yang akan melakukan tutur bicara hendak lah ia mempertimbangkan dari beberapa sisi, apakah topik dan konteksnya tepat, apakah tekanan dan irama suara sesuai, jika hal itu tidak sejalan dengan konsep di atas maka lebih baik memilih diam.

Di samping ayat-ayat Al Quran didapatkan pula Hadits-Hadits yang memperkuat betapa penting kedudukan berbicara atau kata di dalam pandangan Islam, diantaranya adalah: Hadits Riwayat Ibnu Abidun-ya: "Barang siapa yang menahan lisannya (dari kata-kata yang tidak baik), maka Allah menutup celanya dan barang siapa mengekang kemarahannya, maka Allah melindunginya dari siksaNya, dan barang siapa yang menyatakan keudzurannya kepada Allah maka Allah menerima pernyataannya udzurnya itu" (HR Ibnu Abidun-ya). Hadits di atas terkait dengan pengendalian emosi, pemilihan dan pertimbangan dari segi manfaat terhadap dampak dari bericara, apakah efektif atau tidak, serta berbicaralah tentang masalah yang diketahui.

Kedua, kecerdasan logis matematis: di dalam keterangan di atas Gardner menyatakan bahwa kecerdasan logis matematis melibatkan kesanggupan (capacity) untuk menganalisis problem secara logis, mengatsi problem matematika serta sanggup menginvestigasi suatu permasalahan sesuai kaidah keilmiahan. (Logical-Mathematical Intelligence involves the capacity to analyze problem logically, carry out mathematical operation, and investigates issues scientifically). Berpikir dan berdialog, dinyatakan dalam ayat $\mathrm{Al}$ Quran terutama berkaitan dengan kisah Nabi Ibrahim mayoritas bergaya dialog yang berjumlah $83.12 \%$ atau 197 ayat dari 237 yang tersebar dalam 25 surat. Dalam berdialog ketajaman pikiran dan alasan yang tepat serta rasional harus dapat diutarakan. Oleh karena itu seseorang harus menggunakan semua potensi berpikir yang ada di dalam dirinya. Dalam Al Quran surat yang ke 58 Al-Mujadilah, ayat 11, Tuhan berfirman: "...niscaya Allah akan meninggikan orang-orang yang beriman di antara kamu dan orang-orang yang berilmu pengetahuan beberapa derajat." (Q.S. Al Mujadilah (58): 11).

Berfikir dalam Islam didasari pada $\mathrm{Al}$ Quran surat an Nahl ayat 11 sd 14 yang di ringkas sebagai berikut "Agama adalah untuk orang-orang yang berfikir (Afala tatafakkarun)". "agama adalah untuk orangorang yang berakal (afala ta'kilun)”. Al Quran surat an Nahl ayat 11 sd 14 yang berbunyi sebagai berikut: "Dia menumbuhkan bagi kamu dengan air hujan itu tanam-tanaman; zaitun, korma, anggur dan segala macam buah-buahan. Sesungguhnya pada yang demikian itu benar-benar ada tanda (kekuasaan Allah) bagi kaum yang memikirkan. (An Nahl ayat 11) dan "Dia menundukkan malam dan siang, matahari dan bulan untukmu. dan bintang-bintang itu ditundukkan (untukmu) dengan perintah-Nya. Sesungguhnya pada yang demikian itu benar-benar ada tandatanda (kekuasaan Allah) bagi kaum yang memahami (Nya)", (An Nahl ayat 12). dan "Dia (menundukkan pula) apa yang Dia ciptakan untuk kamu di bumi ini dengan berlain-lainan macamnya. Sesungguhnya pada yang demikian itu benar-benar terdapat tanda (kekuasaan Allah) bagi kaum yang 
mengambil pelajaran". (An Nahl ayat 13). "Dan Dia-lah, Allah yang menundukkan lautan (untukmu), agar kamu dapat memakan daripadanya daging yang segar (ikan), dan kamu mengeluarkan dari lautan itu perhiasan yang kamu pakai; dan kamu melihat bahtera berlayar padanya, dan supaya kamu mencari (keuntungan) dari karunia-Nya, dan supaya kamu bersyukur". (An Nahl ayat 14). Hal demikian juga diperkuat Hadits yang diriwayatkan oleh Muslim: "Barangsiapa menempuh jalan untuk menuntut ilmu, niscaya Allah membawanya ke suatu jalan menuju surga." (H.R. Muslim).

Ketiga, kecerdasan ruang, Gardner menyatakan dalam keterangan di atas bahwa kecerdasan ruang (spatial) memiliki potensi untuk mengenal dan memanipulasi pola ruang yang luas dan pola ruang yang kecil. (Spatial Intelligence features the potential to recognize and manipulate the patterns of wide space as well as as the pattern of more confined area).

Firman Tuhan dalam al Quran surat An Nahl ayat 78, berbunyi: "Dan Allah mengeluarkan kamu dari perut ibumu dalam keadaan tidak mengetahui sesuatu pun dan Dia memberi kamu pendengaran, penglihatan, dan hati agar kamu bersyukur" (QS.16:78). Ayat di atas menunjukkan bahwa Tuhan memberikan manusia kecerdasan pendengaran, penglihatan, dan hati. "Penglihatan" merupakan kecerdasan yang terkait dengan kecerdasan visual. Howard Gardner menyebutnya dengan kecerdasan visual spatial.

Keempat, kecerdasan musik: Gardner menyatakan dalam keterangan di atas bahwa Kecerdasan musik terkait dengan kepiawaian dalam menampilkan, mengarang dan menyusun serta mengapresiasi pola musik. (Musical Intelligence entails skills in the performance, composition and appreciation of musical patterns). Di dalam Islam apresiasi terhadap kecerdasan musik ini mendapat tempat yang baik, karena
Tuhan menyenangi akan keindahan. Hal ini terbukti dari penghargaan yang terlihat pada irama ketika membaca Al Quran dan rima ayat-ayat $\mathrm{Al}$ Quran yang banyak berbentuk dan tersususn secara poetis, serta nyanyian dan alunan suara ketika melakukan azan sebagai pertanda bahwa waktu shalat telah masuk.

Kelima, kecerdasan raga (fisik): Di dalam keterangan di atas Gardner menyatakan bahwa Kecerdasan raga (Bodily Kinesthetic) melibatkan kesanggupan anggota badan untuk mengatasi masalah atau tampil dihadapan publik dan memiliki potensi untuk menggunakan fisik secara keseluruhan. Bodily Kinesthetic Intelligence entails those parts of the body to solve problems or fashion products. potential of using one's whole. Kemudian Hadits berikut terkait dengan kecerdasan kinestetik ini yang berbunyi: "Ajarkanlah kepada putra putri kalian berenang dan memanah." (HR. Ibnu Mandah). "Ajarkanlah kepada putera-putera kalian memanah, karena itu merupakan kekuatan penolak musuh.” (HR. Dailami).

Kedua Hadits di atas menunjukkan bahwa agama menyuruh ummatnya untuk mengajarkan anak-anaknya untuk bisa berenang dan memanah, menunggang kuda karena hal itu merupakan kekuatan penolak musuh dan menghidupi diri dengan rezki yang halal. Hal demikian merupakan kemampuan fisik yang bersifat kinestetik. Oleh karena itu Hadits di atas terkait dengan kecerdasan kinestetik. Di samping nilai afeksi Hadits berikut ini menunjukkan bahwa ajaran Islam mewajibkan penguasaan keterampilan fisik (psikomotorik). Memang dalam kedua Hadits tersebut di atas disebutkan kata-kata berenang dan memanah sebagai suatu hal yang sangat spesifik, namun pada hakikatnya kedua kompetensi tersebut merupakan keterampilan fisik (psikomotorik).

Keenam, kecerdasan sosial: Gardner menyatakan bahwa kecerdasan hubungan sosial (Interpersonal Intelligence) menunjuk 
kepada suatu kapasitas untuk memahami keinginan (intenstions) dan motivasi seseorang. Hal ini juga terkait dengan kehendak atau keinginan orang lain serta bisa bekerja sama dengan pihak lain tersebut (Interpersonal Intelligence denotes person's capacity to understand the intentions, motivasions, and desires of other people and, consequently, to work effectively with others).

Hadits berikut ini kecerdasan interpersonal yang berbunyi "Sesungguhnya kamu manusia tidak dapat mempergauli para manusia itu hanya dengan hartamu saja, maka pergaulilah mereka itu dengan wajah berseri-seri serta baiknya budi pekerti". (HR. Bazzar, Abu Ya'la dan Thabrani). Hadits di atas menunjukkan bahwa agama menyuruh manusia mempergauli mereka itu dengan wajah berseri-seri serta baiknya budi pekerti. Ayat di atas terkait dengan kecerdasan interpersonal. Kecerdasan ini terkait dengan kemampuan membangun dalam mempertahankan hubungan dengan orang lain dengan memahami dan memperkirakan perasaan, temperamen, suasana hati, maksud dan keinginan orang lain dan menanggapinya secara layak, hal ini terkait dengan empati yaitu memahami perasaan orang lain dari sudut pandang orang tersebut. Kecerdasan ini memungkinkan seseorang untuk membangun kedekatan, pengaruh, kepemimpinan dan hubungan dengan masyarakat.

Ketujuh, kecerdasan diri pribadi: Gardner menyatakan dalam keterangan di atas bahwa kecerdasan diri pribadi (Intrapersonal intelligence) merupakan kemampuan untuk memahami diri sendiri yang terkait dengan kelebihan dan kekurangan, model dan cara kerja. Hal demikian juga termasuk keinginan, ketakutan serta kemampuan untuk memanfaatkan informasi secara efektif dalam mengatur kehidupan sendiri. (Intrapersonal intelligence involves the capacity to understand oneself, to have an effective working model of oneself including one's own desires, fears, and capacities and to use such information effectively in regulating one's own life).

Nabi Muhammad menegaskan tujuan kehadiran beliau sebagai utusan Tuhan di bumi ini tentang keutamaan akhlak atau budi pekerti. Hadits riwayat Ahmad berikut ini menunjukkan pentingnya nilai-nilai afeksi tersebut dalam hal pendidikan: "Aku diutus di muka bumi untuk menyempurnakan akhlak" (HR. Ahmad).

Kedelapan, kecerdasan naturalis: kecerdasan ini terkait dengan kemampuan untuk mengenali, membedakan, menggolongkan dan membuat kategori terhadap apa yang dijumpai; alam, flora dan fauna di lingkungan maupun di alam sejagad ini. Inti dari kecerdasan ini adalah kemampuan manusia untuk mengenali tanaman, hewan dan bagian lain dari alam semesta. (Natural Intelligence,denotes the capacity to demonstrate expertise in the recognition and classification of the numerous species -the flora and the faunaof his or her environment... ... A naturalist is a biologist who recognize and categorized specimens ... and extensive knowledge of the living world).

Di dalam keterangan di atas Gardner menyatakan bahwa Kecerdasan naturalis (natural) melibatkan kapasitas untuk mengklasifikasikan dan memahami kehidupan dari makhluk hidup flora dan fauna. Selanjutnya, Al Quran menyebut berkali-kali tentang kejadian bumi, langit atau alam semesta seisinya dan tentang flora dan fauna, serta pemilharaan melarang membuat kerusakan di atas bumi, yang demikian itu terkait dengan kecerdasan naturalis. Dalam Al Quran Surat Al Baqarah ayat 205 dan Surat Al A'raaf:56 Tuhan berfirman bahwa: "Dan apa bila ia berpaling (dari kamu) ia berjalan dibumi untuk mengadakan kerusakan padanya, dan merusak tanam-tanaman dan binatang ternak, dan Allah tidak menyukai 
kebinasaan.” (QS. Al Baqarah: 205). "Janganlah kalian berbuat kerusakan di muka Bumi setelah Allah memperbaikinya" (Al A'raaf: 56). Ketika Islam melarang perbuatan tersebut, maka itu adalah untuk menjaga binatang dari pencemaran air, udara dan tumbuhan. Ini adalah hak setiap makhluk. Dalam skala luas kecerdasan ini terkait dengan alam mikro dan makro kosmos.

Kesembilan, kecerdasan tasauf (sufi). Ketika Islam berbicara tentang rohani, hal ini bukan hanya berarti tingkah laku (behaviour) dan (attitude) melainkan terkait dengan suatu ranah yang jauh melampaui materi di dalam batin seseorang. Dalam hal ini Islam berbicara tentang jiwa yang ranahnya meliputi rasio, emosi, dan qalbu. Lebih dalam Philip H. Phenix menyatakan bahwa ranah agama, tidak hanya sekedar pada sikap atau ranah afeksi saja namun jauh lebih menjamah kedalam ranah batin. Menurutnya"the personal God is believed to be the source and ground of created persons. The traditional term of the person regarded from an ultimate perspective is the" soul" by which is meant to the real core of a person's being, as contrasted with the empirical self whose characteristics can be described in the categories of finitude. The soul is the mysterious depth in persons, in which are hidden the inexhaustible possibilities of being."

Pendapat di atas menyatakan bahwa dilihat dari hakikat kehidupan, maka hakikat manusia adalah jiwa, yang jauh di kedalaman batin, bukan pada yang tampak oleh indra. Jiwa merupakan kekuatan batin yang misterius (mysterious depth) di dalam diri seorang individu.Tuhan adalah Sesuatu yang Maha Kuasa, Maha Pencipta dan sekaligus sebagai sumber dan sentra dari ciptaanNya.

Dalam hal ini dapat ditarik sebuah pengertian dari Phenix bahwa ranah agama jauh sampai ke dalam batin seseorang yang melebihi afeksi. Agama bukan sekedar ritual formal atau diukur dengan indra sebatas penglihatan atau pendengaran yang bersifat empiris. Agama menjamah ranah batin manusia yang disebut dengan jiwa. Jiwa merupakan esensi atau hakikat manusia yang sesungguhnya.

Kedelapan kecerdasan tersebut dapat digolongkan bahwa manusia tidak terlepas dari hubungannya dengan: alam, flora, fauna, manusia dan masyarakat, Dari situ dapat dianalogkan bahwa manusia juga membutuhkan hubungannya dengan Tuhan. Membina hubungan antara manusia dengan Tuhan merupakan penyatuan antara intuisi atau qalbu (bukan fisik) manusia dengan Tuhan. Hal ini dapat merupakan juga kemampuan yang hanya dapat dicapai dengan kecerdasan. Penyatuan intuisi manusia dengan Tuhan baru dapat dicapai setelah menempuh beberapa tingkatan pengalaman dan pengetahuan yang bersifat hirarkis. Jika tingkatan bawah belum lulus dilampaui maka tingkatan atas tidak akan dapat dicapai, sehingga penyatuan dengan Tuhan sebagai puncak kebahagian dan kesenangan tidak akan tercapai.

Tujuan hidup tertinggi dari manusia adalah bertemu dengan Tuhan baik di dunia maupun diakhirat kelak. Oleh karena itu hakekat dari penyatuan manusia dengan Tuhan adalah merupakan penanaman akhlak manusia yang tinggi, yaitu internalisasi nilai nilai afeksi dalam diri manusia itu sendiri. Cara demikian merupakan usaha penanaman atau pembatinan nilai-nilai afeksi dalam tasauf. Sebagaimana diketahui bahwa tasauf merupakan salah satu pendekatan dari empat pendekatan terhadap Tuhan dalam agama Islam.

\section{Gagasan Penerapan}

Bakat merupakan potensi tersembunyi dibawa sejak lahir yang telah melekat dengan kepribadian seseorang, yang siap untuk diaktualisasikan dan akan berkembang lebih baik jika terjadi sinergi dengan lingkungan yang mendukung disekitarnya. 
Sebagaimana terlihat dalam Hadits riwayat Bukhari Muslim berikut ini: "Tiap anak yang dilahirkan membawa fitrah, ayah dan ibunyalah yang menjadikannya Yahudi, Nasrani atau Majusi" (Hadits riwayat Bukhari Muslim).

Ayat Al Qur'an dan hadits di atas menyatakan bahwa anak manusia semenjak lahir telah membawa fitrah atau kodrat kejiwaan yang diwarisi dari orang tuanya, kodrat tersebut merupakan potensi atau kemampuan yang merupakan kekuatan dirinya untuk mencari kebenaran, belajar atau mengabdi kepada Tuhan. Ayat di atas juga menunjukkan bahwa fitrah merupakan suatu potensi yang bisa diarahkan, dibentuk dan dikembangkan oleh lingkungan. Sebagaimana Hadits menyatakan "Ayah dan Ibunyalah yang menjadikan anak tersebut Yahudi, Nasrani ataupun Majusi”, artinya ayah dan ibu yang berfungsi sebagai faktor lingkungan dari seorang anak yang memiliki potensi untuk mengarahkan anak tersebut sesuai dengan keinginannya.

Jika fitrah merupakan suatu potensi yang dibawa semenjak lahir, sedangkan bakat juga merupakan suatu potensi yang dibawa dari lahir maka antara fitrah dan bakat dalam konteks di atas memiliki pengertian yang sama. Islam yang meyakini bahwa setiap anak yang dilahirkan membawa fitrahnya dan sekaligus fitrah ini membedakan satu dari yang lainnya. Seorang anak yang lahir membawa bakat dalam dirinya yang sekaligus merupakan cikal bakal kekuatan di dalam dirinya, namun diakui, aktualisasi diri anak tercipta sebagai akibat interaksi antara anak dengan lingkungannya. Sinergis keduanyalah yang menjadikan anak itu sebagai apa adanya, artinya anak yang terlihat pada suatu saat, walaupun dalam kondisi berbeda, semua itu merupakan produk dari sinergis antara anak sebagai seorang individu dengan lingkungannya.

Keterangan di atas menjelaskan bahwa ada dua faktor yang mempengaruhi perkembangan potensi anak manusia. Pertama, faktor genetis yaitu faktor yang berkaitan dengan sifat bawaan; bakat, kecerdasan, emosi, spiritual dan motivasi yang ada dalam diri peserta didik. Kedua, faktor lingkungan, hal ini berkaitan dengan semua sumber informasi yang berasal dari luar diri peserta didik; seperti orang tua, keluarga, teman, pendidik dan masyarakat sebagai sumberdaya manusia, buku, internet, multi media. Hal ini juga mencakup semua pergaulan dan pengalaman atau pendidikan yang diperoleh anak di dalam dan di luar sekolah.

Setelah dicermati maka dapat disimpulkan bahwa bakat, fitrah maupun kecerdasan jamak adalah merujuk pada suatu maksud dan makna yang sama, hanya saja yang membedakan adalah sisi memandang dari latar belakang yang berbeda. Artinya sebelum penemuan kecerdasan jamak oleh Howard Gardner, diyakini hanya ada bakat, sedangkan setelah penemuan, Howard Gardner menegaskan bahwa semua anak yang lahir membawa lebih dari satu kecerdasan bahkan dapat dikelompokkan atas delapan kecerdasan.

Sesuai dengan pernyataan tersebut di atas, maka pelacakan bakat dan pengembangannya sebagai sebuah potensi kecerdasan seharusnya dilaksanakan semenjak awal dari pendidikan dimulai, baik formal maupun informal. Untuk itu pendidikan awal yang dilakukan di rumah tangga maupun pada pendidikan di sekolah (pendidikan formal) seperti prasekolah (Preschool), TK (Kinder Garten) dan SD (Primary School) seyogianya menitik beratkan pendidikan kearah pelacakan bakat dan pengembangan potensi kecerdasan yang dimiliki masing-masing peserta didik. Materi pembelajaran yang diambil terlalu banyak jumlahnya, seperti di SMA antara 13 sampai 15 mata pelajaran. Dengan jumlah materi yang telalu banyak, menjadikan peserta didik kekurangan waktu atau peluang untuk berkreasi, karena ada yang cenderung 
berpendapat bahwa "semakin banyak tugas yang dibebankan, semakin pintar peseta didiknya". Tanpa disadari jumlah materi yang berlebihan (over loaded) akan memperkecil peluang masa inkubasi ilmu sehingga memandulkan kreatifitas peserta didik.

Dalam usaha pelacakan bakat dan kecerdasan, setiap peserta didik secara berkelanjutan harus dihadirkan dengan pilihan-pilihan materi pembelajaran dan pilihan yang diminatinya sehingga terhindar dari campur tangan dan keinginan pendidik yang memaksakan kehendaknya. Hal ini merupakan ekspresi keinginan yang sesuai dengan panggilan bakat dan kemampuan yang dimiliki. Oleh karena itu penyajian materi dalam bentuk paket yang wajib dipelajari oleh peserta didik tidak lagi cocok dengan pelacakan bakat dan pengembangannya. Moving class system, yaitu pemilihan oleh peserta didik terhadap pendidik (guru) yang diinginkannya dalam suatu institusi harus difasilitasi, artinya kalau dulu pada setiap satuan pendidikan guru/pendidiklah yang masuk kedalam kelas murid, sebaliknya dalam kondisi yang diusulkan, muridlah yang masuk kedalam kelas guru.

Di samping itu perlu disiapkan suatu sistem pembelajaran silang (Travelling Students) yang memungkinkan peserta didik dari suatu satuan pendidikan bisa ikut serta mengambil beberapa mata pelajaran ditempat lain dalam wilayah geografis ( dalam satu kelurahan atau kecamatan) yang sama. Dalam halaqah sistem (U Style) yang diperkenalkan oleh Nabi Muhammad, peserta didik disarankan untuk duduk melingkar di sekitar guru bukan sebaliknya menjauhi guru dengan duduk berbanjar ke belakang, sehingga peserta yang satu berada di belakang lainnya. Hal ini memungkinkan terjadinya penghindaran kontak lansung dengan pendidik. Oleh karena itu peserta didik bisa membentuk tempat duduk berkelompok empat sampai enam kelompok dalam satu kelas dengan mengosongkan tempat di tengah-tengah untuk pendidik dan peserta didik agar dapat berpindah tempat atau bergerak dengan bebas. Setiap kelompok terdiri dari empat sampai enam orang.

Untuk mempelajari materi baru kesiapan peserta didik haruslah menjadi utama, pengutamaan tersebut berupa kesiapan mental dan intelektual. Pembelajaran dengan materi yang lompat, tanpa adanya kesiapan merupakan beban yang berat. Dalam hal ini Islam merespon dengan wahyu Tuhan dalam surat Al Baqarah ayat 286, "Allah tidak membebani seseorang melainkan sesuai dengan kesanggupannya. Ia mendapat pahala (dari kebajikan) yang diusahakannya dan ia mendapat siksa (dari kejahatan) yang dilakukannya" (QS. 2 : 286).

Ayat di atas menjelaskan bahwa, manusia memiliki kesanggupan, tapi kesanggupan itu memiliki batas. Oleh karena itu terkait dengan kapasitas beban bagi seorang manusia, Tuhan memperingatkan bahwa beban tersebut jangan melebihi kapasitasnya. Dalam pembelajaran, materi yang diberikan mestilah memiliki tujuan yang jelas dan merupakan suatu kesatuan yang utuh (tidak terpencar atau parsial). Oleh karena itu materi baru merupakan pendalaman atau kelanjutan dari materi sebelumnya, sehingga materi baru bukanlah merupakan materi yang lompat tanpa ada persiapan dan kesiapan, melainkan bersifat berjenjang.

Untuk memperkaya wawasan peserta didik dalam mengembangkan kecerdasannya, lingkungan pendidikan yang menunjang haruslah dihadirkan kepada setiap peserta didik agar terjadi sinergi antara dua kekuatan yang berasal dari dalam diri peserta didik berupa fungsi kerja otak, bakat dan kecerdasan, sedangkan yang lainnya berasal dari luar diri peserta didik yaitu lingkungan pendidikan, yaitu suasana belajar yang menyenangkan, fasilitas yang 
lengkap, metode pembelajaran yang sesuai, keterampilan interpersonal dan kualifikasi pendidik yang memadai.

Suasana belajar terkait dengan tempat dan waktu yang sangat penting di pertimbangkan. Tempat penyelenggaraan pendidikan harus bebas dari lingkungan yang mudah mengganggu konsentrasi dan perhatian peserta didik, misalnya kebersihan lingkungan, kebersihan diri sendiri. Jika tempat dan lingkungan tidak terencana dengan baik keduanya bukanlah merupakan faktor pendukung yang memotivasi. Pertama, kebersihan, di dalam Islam hal ini di tegaskan secara jelas dalam Hadits berikut ini "kebersihan adalah setengah iman (Hadits riwayat)". Begitu pentingnya kebersihan di dalam agama Islam, sehingga kebersihan dikaitkan dengan keyakinan (iman) seseorang. Kedua, ruangan kelas juga sangat menentukan, sirkulasi udara yang bebas (airy) dan jarak ideal dari keramaian atau suara ribut dan bunyibunyian haruslah dirancang sedemikian rupa. Pelataran halaman memberi kesan yang luas dan terhindar dari kondisi luapan air, banjir atau genangan. Ketiga, untuk sebuah motivasi tinggi dan pembentukan jati diri agar lebih percaya diri dan rasa tanggung jawab, maka karya-karya peserta didik ditampilkan dan dipajang .disekitar lingkungan sekolah.

Begitu juga dengan waktu belajar, pada umumnya belajar optimal bisa diraih ketika suasana nyaman, tenang dan santai (relaxed) serta ketersediaan waktu yang cukup untuk beristirahat, sungguhpun ada pendapat yang mengatakan bahwa kapan saja orang bisa belajar.

Pendidikan tentang kesucian jiwa sebagai mana dinyatakan dalam pendapat tasauf di atas harus dilakukan terhadap kedua orang tua bayi yang akan mewariskan sifat dan kepribadian kepada bayinya kelak. Hal ini sangat logis karena secara bilogis bayi berasal dari darah dan tubuh kedua orang tuanya. Tentang kapan pendidikan berakhir, Lebih lanjut dinyatakan bahwa pendidikan akan berakhir pada saat seseorang berhadapan dengan ajalnya. Pengertian yang bermakna jelas bahwa pendidikan masih harus diberikan kepada seseorang walaupun pada saat-saat menghadapi maut. Perlakuan tersebut diajarkan dengan mengucapkan kalimat zikir yang berbunyi "tiada Tuhan melainkan Allah"

\section{KESIMPULAN}

Howard Gardner, pada tahun 1983, seorang ahli biopsikologi, menemukan bahwa di dalam diri manusia terdapat potensi kecerdasan yang beragam, dan telah melekat semenjak dilahirkan. Secara empiris Howard Gardner membuktikan bahwa di dalam diri setiap individu terdapat setidaknya delapan kecerdasan. Inti dari pemikiran terkait dengan pendidikan Howard Gardner adalah Multiple intelligence sebagai approach, method dan classroom technique dalam perspektif $\mathrm{M}$. Anthony.

Berikut ini digambarkan kedelapan kecerdasan tersebut yang sekaligus dipandang dari sisi hubungannya dengan objek yang terkait. Pertama, kecerdasan bahasa terkait dengan organ artikulasi dan pikiran. Kedua, kecerdasan logis-matematik terkait dengan akal manusia. Ketiga kecerdasan raga terkait dengan kepintaran fisik. Keempat kecerdasan interpersonal terkait dengan emosi diri sendiri dan dengan orang lain. Kelima kecerdasan intrapersonal terkait dengan akal dan emosi di dalam diri sendiri. Keenam kecerdasan spatial dengan ruang mikro dan makro. Ketujuh kecerdasan musik dengan emosi. Kedelapan kecerdasan naturalis dengan alam, flora dan fauna.

Kedelapan kecerdasan tersebut dapat dikatakan bahwa manusia tidak terlepas dari hubungannya dengan otak, logika, emosi atau jiwa.. Disamping itu ada lagi hubungan khusus antara manusia dengan alam sekeliling seperti, flora, fauna, alam 
dan manusia atau masyarakat. Kalau hubungan kecerdasan itu dengan objeknya dianalisis maka dapat disimpulkan bahwa kecerdasan tidak bisa tidak membutuhkan hubungan dengan objeknya seperti hubungannya dengan alam, hewan, tumbuhan dan manusia termasuk jiwa, emosi dan rasio di dalam diri manusia, Maka, oleh karena itu wajar saja jika ada satu hubungan lain yang seharusnya ada, yaitu hubungan yang mengatur antara manusia dengan Tuhan.

Kecerdasan yang mengatur hubungan antara manusia dengan Tuhan ini berorientasi pada peningkatan jenjang akhlak, mulai dari jenjang paling bawah menuju jenjang paling atas sebagai usaha mencari kebahagiaan di dunia dan sekali gus akhirat yaitu bersatu dengan Tuhan. Dalam hal hubungan manusia dengan Tuhan tersebut penulis menamakannya kecerdasan tasauf (Sufism Intelligences).

Walaupun Howard Gardner mengemukan kecerdasan tentang moral, ada pada kecerdasan diri pribadi atau kecerdasan sosial, namun orientasinya berbeda. Perbedaanya adalah pada tujuan, kecerdasan tasauf mengatur hubungan dunia dan akhirat, sehingga menghasilkan model akhlak yang berbeda dengan Howard Gardner yang tidak melibatkan hubungan ke akhirat atau masa depan yang hakiki. Hal demikian seiring dengan hakikat manusia sebagai makhluk yaitu makhluk "Homoreligious". manusia tidak terlepas dari kehidupan beragama. Homoreligious, memperkuat hubungan yang seharusnya ada yaitu hubungan yang mengatur antara manusia dengan Tuhan. Hubungan tersebut sangat berpotensi tinggi dalam membangun dan mengembangkan akhlak manusia yang berorientasi pada peningkatan jenjang akhlak, mulai dari jenjang paling bawah menuju jenjang paling atas.

Dalam tradisi tasauf (sufism Intelligence) yaitu besatunya manusia dengan Tuhan (bukan fisik melainkan qalbu atau intuisinya) merupakan kondisi puncak. Kondisi puncak demikian ini hanya dapat dicapai setelah menempuh beberapa tingkatan pengalaman dan pengetahuan yang besifat hirarkis. Jika tingkatan bawah belum lulus dilampaui maka tingkatan atas tidak akan dapat tercapai, sehingga penyatuan dengan Tuhan sebagai puncak kebahagian dan kesenangan tidak akan tercapai.

Oleh karena itu kecerdasan tasauf, merupakan pendekatan kepada Tuhan secara intens melalui Qalbu (intuisi), dan produk tasauf tersebut telah membuktikan dirinya sebagai suatu dimensi kerohanian yang mampu membawa manusia berprilaku baik dan terpuji. Berbeda dari spiritual intelligence, kecerdasan tasauf (Sufism Intelligence) menggali hakikat yang bersumber pada Tuhan (Allah), yaitu Yang menciptakan alam jagad raya. Hakikat dari suatu prilaku dalam pandangan tasauf merupakan kecintaan dan keikhlasan kepada Sang Pencipta yaitu Tuhan Penguasa alam Semesta yang melebihi cinta terhadap materi.

Kedelapan kecerdasan yang bersifat holistik seperti yang diuraikan di atas merupakan realisasi dari empat pendekatan kepada Tuhan dalam Islam yaitu Syari'ah, Filsafat, Tasauf dan Ilmu Kalam, yang akhirnya keempat aliran itu bermuara pada satu kesatuan yaitu hubungan kepada Tuhan "Allah". Oleh karena itu Pembelajaran dalam tradisi islam bersifat holistik mencakup seluruh ranah potensi belajar, akal (qalbu), emosi (jiwa, nafs). Dengan kata lain pembelajaran dalam tradisi Islam melibatkan seluruh potensi diri termasuk potensi tasauf, yang dalam pandangan Howard Gardner disebutnya dengan istilah kecerdasan.

Hakikat pendidikan Islam yang dapat disimpulkan dari kecerdasan tasauf (Sufism Intelligence) adalah pengenalan diri yang sangat mendasar kedalam batin agar dapat mengabdikan diri kepada Tuhan. Mengenal diri diartikan sebagai mengenal sifat Tuhan, 
yang dalam satu aliran disebutkan berjumlah Sembilan puluh Sembilan sifat. Manusia pun penyayang, pengasih, pendamai, pemimpin, pencipta, dan lainya itu namun hal demikian merupakan satu kesatuan yang tidak dipisahpisahkan. Keseluruhan sifat demikian adalah tauladan. Setiap manusia sebagai khalifah, pendidik harus memberikan tauladan kepada sesama ummat manusia.

Kecerdasan jamak versi Howard Gardner merupakan strategi (metodologi) pembelajaran yang memenuhi tiga persyaratan sebagaimana dikemukan oleh Edward M. Anthony. Baik sebagai sebuah pendekatan (approach) yang bersifat aksiomatik (keyakinan), sebagai sebuah metode yang bersifat prosedural maupun sebagai sebuah teknik aplikasi pembelajaran di dalam kelas.

Landasan pendidikan Islam adalah pengabdian total kepada Tuhan karena manusia diciptakan Tuhan untuk mengabdi kepadaNya, sejalan dengan landasan pendidikan maka materi pendidikan bersifat tauhid searah dengan keesaan Tuhan. Oleh karena itu materi yang tidak layak dalam kaca mata Islam harus ditinggalkan. Secara hakikat perbedaan utama antara pendidikan Barat dan pendidikan Islam terdapat pada tujuan pendidikan. Pendidikan Barat bertujuan meraih kebahagian hidup di dunia semata sedangkan pendidikan Islam bertujuan untuk meraih kebahagiaan hidup di dunia dan sekaligus di akhirat oleh karena itu tujuan pendidikan Islam memiliki nuansa futuristik. Maksudnya kehidupan manusia didunia dikaitkan dengan kehidupan akhirat kelak dalam penanaman nilai-nilai akhlak. Materi pendidikan dalam Islam bukan saja ditujukan hanya untuk mencapai kebahagian hidup di dunia, melainkan ada keberimbangan antara dunia dan akhirat, maka integralisasi ilmu dan nilai-nilai spiritual di dalam pembelajaran menjadi utama. Oleh karena itu prinsip belajar sepanjang hayat merupakan keharusan dalam Islam.
Setiap manusia memiliki kekhasan atau sifat dan kepribadian masing-masing, hal ini memberi arti bahwa peserta didik diberi kebebasan untuk memilih materi yang sesuai dengan potensi diri seperti kemampuan, bakat, intelegensi, gaya belajar bahkan gaya berfikir dan akhlak (tasauf). Agar fokus pendidikan diarahkan untuk mencari dan mengembangkan kecerdasan (bakat) yang dimulai dari sedini mungkin. Pemebelajaran pada TK, SD, lebih tertuju pada pencarian dan penemuan kecerdasan sedangkan pembelajaran lebih lanjut tertuju pada pengembangan kecerdasan tersebut.

Moving class system, yaitu pemilihan oleh peserta didik terhadap pendidik (guru) yang diinginkannya dalam suatu institusi artinya kalau dulu pada setiap satuan pendidikan guru/pendidiklah yang masuk kedalam kelas murid, sebaliknya dalam kondisi yang diusulkan, muridlah yang masuk kedalam kelas guru. Disamping itu perlu disiapkan suatu sistem pembelajaran silang (Travelling Students) yang memungkinkan peserta didik dari suatu satuan pendidikan bisa ikut serta mengambil beberapa mata pelajaran ditempat lain dalam wilayah geografis ( dalam satu kelurahan atau kecamatan) yang sama. Materi pembelajaran yang diambil telalu banyak jumlahnya, seperti di SMA antara 13 sampai 15 mata pelajaran. Jumlah materi demikian, menjadikan peserta didik kekurangan waktu atau peluang untuk berkreasi yang memandulkan kreatifitas peserta didik.

Howard Gardner Oleh karena itu peserta didik disarankan membentuk tempat duduk berkelompok yang jumlahnya antara empat sampai enam kelompok dalam satu kelas dengan mengosongkan tempat di tengah-tengah untuk pendidik. Hal demikian dimaksudkan juga agar peserta didik dapat dengan mudah berpindah tempat atau bergerak dengan bebas. Setiap kelompok terdiri dari empat sampai enam orang agar komuniskasi di antara sesama peserta didik 
lebih hidup dan mendapat giliran yang lebih banyak, merata serta intens. Sehingga di dalam kelas terjadilah hubungan di antara peserta didik yang sangat bersifat sosial.

\section{REFERENSI}

Anderson, Orin. W, et al. A Taxonomy for Learning, Teaching, and Assesing. United States: Longman, 2001

Badan Pusat Statistik (BPS). BPPS Siapkan Sensus Penduduk 2010. 2009. (http://www.antaranews.com/view/?i=12440 $43378 \& \mathrm{c}=\mathrm{EKB} \& \mathrm{~s}=\mathrm{MAK})$

Bryman, Alan. Social Research Methods. USA: Oxford University Press, 2001.

Buzan, Tony. Brain Child. Jakarta: Gramedia Pustaka Utama, 2005.

Center for Moderate Moslem (CMM), Membangkitkan Umat dengan Iptek, 2008.http://www.cmm.or.id/cmm-ind

more.php?id=5128 $0360 \mathrm{M} 15$

Clark, Barbara. Growing Up Gifted, Developing the Potential of children at home and at school, second Edition, Charles E. Colombus: merrill Publishing company, A bell \&Howell company, 1986.

Creswell, John W. Qualitative Inquiry and Research Design. USA: Sage Publication, 1998.

Frager, Robert. (Syekh Ragib al Jerahi), Terjemahan Oleh Hasymiah Rauf, Heart, Self, \& Soul: The sufi Psychology of Growth, Balance and Harmony, theological Publishing House, Wheaton, 1999. Judul terjemahan, Hati, Diri, Jiwa. Jakarta: Serambi, 2005
Gardner, Howard, Changing Minds, Massachusetts,USA, Hardvard Business School Press, , 2006.

Gardner, Howard. Frames of Mind, The Theory of Multiple Intelligences. Basic Book, USA, The twentieth Anniversary Edition 2004

Gardner, Howard. Intelligence Reframed. Basic Book, USA. 1999

Gardner, Howard. The Unschooled mind. Basic Book, USA. 2004

Goleman, Daniel. Emotional Intelligence. Jakarta: Gramedia Pustaka Utama,1996.

Good T, Brophy J. Educational Psychology, Longman Publishing Company, New York. 1990

Grenz,Stanley J, A Primer on Postmodernism, Jogyakarta, Yayasan andi Ypgyakarta,1996.

Nasution, Harun. Islam Ditinjau dari Berbagai Aspeknya. Jilid I, Jakarta: Universitas Indonesia, 1985.

Nasution, Harun. Falsafat dan Mistisisme dalam Islam. Jakarta: Bulan Bintang, 1995.

Jurnalnet.com.Penduduk Indonesia 2009 capai 231 juta jiwa.2009 (http://www.jurnalnet.com/konten.php?nama $=$ BeritaUtama\&topik $=12 \& \mathrm{id}=1060$ )

Nata, Abudin. Metodologi Studi Islam. Jakarta: PT. Raja Grafindo Persada, 1999.

Phenix, Philip.H. Realms of Meaning. London: Mc Graw Hill Book company, 1964

Pormadi (kristiani pos. Jumlah Umat Islam Lebih Besar daripada Umat Katolik Roma. 2008. 
(http://pormadi.wordpress.com/2008/04/01/j umlah-umat-Islam-lebih-besar-daripadaumat-katolik-roma)

Richards, Jack C, Approach and Method in Language Teaching, Cambridge University Press, Cambridge, 1986.

Richey, Rita C dan Seels Barbara B. Teknologi Pembelajaran. Jakarta: Unit Percetakan Universitas Negeri Jakarta, 1994.

Semiawan, Conny. R. Perspektif Pendidikan Anak Berbakat. Jakarta: Rasindo, 1997.
Siler, Todd, Breaking the Mind Barrier, The Art Science of Neurocosmology, New York, Simon and Schuster, 1990.

Siler, Todd, Think like a Genius, Bantam books, New York, 1999.

Soedijarto, Landasan dan Arah Pendidikan Nasional Kita, Jakarta PT kompas Media Nusantara, 2008.

Tebba, Sudirman, Ruh, Mistery Maha Dahsyat,pustaka IrVan, Jakarta, 2008 